\title{
The Role of Empowerment, Human Capital and Commitments Soldiers Performance in Yonbekang 2 Kostrad Malang
}

\author{
Triyogi Pambudi* \\ Student in Master in Management Program, University of Merdeka Malang, Indonesia \\ Achmad Firdiansjah \\ Graduate Program, University of Merdeka Malang, Indonesia \\ Junianto Tjahjo Darsono \\ Graduate Program, University of Merdeka Malang, Indonesia
}

\begin{abstract}
This study aims to describe Empowerment, Human Capital, Commitment and Soldier Performance in Yonbekang 2 Strategic Reserve Command, to analyze the influence of Empowerment, Human Capital, Commitment and Performance of Soldiers in Yonbekang 2 Strategic Reserve Command, to analyze the which variables of Empowerment, Human Capital and Commitments have a dominant influence on the Warrior Performance at Yonbekang 2 Kostrad. The sample in this study amounted to 114 soldiers. The analysis uses multiple regression analysis technique. The results of the analysis show that empowerment, human capital, and commitment have an effect on the soldier's performance, the which means that the better empowerment, supported by soldiers who have high human capital, and supported by high commitment soldier can improve performance. Human capital has an influence on the performance of soldiers in Yonbekang 2 KOSTRAD Malang. This shows that the main thing that can improve a soldier's performance is its human capital, especially training.
\end{abstract}

Keywords: Empowerment, Human Capital, Commitment, Soldier Performance

DOI: $10.7176 / \mathrm{EJBM} / 11-8-04$

Publication date:March $31^{\text {st }} 2019$

\section{Introduction}

Battalion debriefing Transport 2 KOSTRAD disingka Yonbekang 2 KOSTRAD is one Unit of Assistance Administration (Satbanmin) under the auspices of the Division of Infantry (Divif) 2 KOSTRAD has the main task organize debriefing, maintenance and services Bekang in ARRANTY by land, water and air for the To support the main tasks of the unity of the ranks of Divif 2 Kostrad. As Satbanmin (Administrative Assistance Force), Yonbekang 2 Kostad required to perform their duties optima that the principal task can be achieved. Yonbekang unit 2 KOSTRAD task is inseparable from the performance of the soldiers. Many factors can affect the performance of soldiers are leadership, motivation, work environment, work culture, communication, office, training, empowerment, human capital and compensation.

A soldier can develop and improve, supported by a good empowerment, human capital good and a good commitment, so as to create organizational stability and sense of the soldiers in order to achieve organizational goals embodied in every action and behavior of both leaders and subordinates.

Empowerment soldier provides more opportunities to develop creativity, flexibility autonomy over their own job retention. it is believed will bring beneficial effects in recognition of soldiers. Empowerment by Mahardiani (2004) is giving them responsibility and authority to members of the organization, to plan, control and make decisions about the work that they are responsible, without having received explicit authority from the leadership on it. If a soldier is given an understanding of the empowerment that every soldier will be motivated to perform each task - the task given by Divif 2 Kostrad. In the role of military organization is a tool of empowerment / good program due to changes in the organization and participation in improving the performance of soldiers.

Human Capital Human is the most important asset in the military world, not just as a slogan written on the vision and mission of the organization. Several studies of human capital that human capital elah test positive impact on the performance of the individual, which human capital measured by education level, tenure and training (Hayek, e al., 2014: 7). Samad was also confirmed by a study (2013) which says that human capital erdiri on education, training, knowledge, skills, competencies and attitudes. Crook, e al. (2011) so that by using metaanalysis, explaining that erdapat emuan many studies that prove the influence of human capital on performance.

Commitment within an organization in this case Yonbekang 2 Kostrad is the ability and willingness to align behavior with the needs, priorities and objectives of an organization. Commitment is defined as "The degree o Identifies the which an employee with a particular organizationa and its goals, and wishes he membershipin o maintain organizational" (Robbins, 2007). Members of the organization in this case the soldier is the most important asset in the achievement of organizational goals (Yonbekang 2 Reserve Command), so as to produce a good performance and can make a major contribution in carrying out activities of an organization. In the world of 
one's military commitment in the organization is often a contentious issue important dross. Therefore it can be concluded that the strength of the linear relationship between empowerment, human capital and organizational commitment to performance is strong. Where soldiers always implement empowerment, human capital and commitment to the well. Empowerment, human capital and commitment will increase the likelihood ercapainya peak performance.

The dynamics of the development of human resources in Yonbekang 2 Kostrad are diliha and employment performance observed ewa soldiers. Therefore, this study will examine the effect of empowerment, human capital and commitment to the performance of soldiers, where the application of the role of empowerment, human capital and commitment in Yonbekang 2 Kostrad, so as to encourage soldiers to work better. Human Resources is based on an increase in the quality of the soldiers in this military organization, the researchers ertarik to examine the role of empowerment, human capital and commitment to improving the performance of soldiers.

Objective is to describe Empowerment, Human Capital, Commitment and Performance Soldiers in Yonbekang 2 Kostrad, to analyze the influence of Empowerment, Human Capital, Commitment and Performance Soldiers in Yonbekang 2 Kostrad, and to analyze Where variable Empowerment, Human Capital and commitment to the dominant influence performance against soldier in Yonbekang 2 Kostrad.

\section{Literature}

\section{1. performance}

Performance is the value of a series of behaviors of workers who contribute both positively and negatively, on completion of organizational goals (Colquit e al., 2011: 35). according Kazlauskaite et al., (2012: 86), the performance includes all the business objectives of the organization. For tingka leadership under performance is the goal of management tasks to achieve performance as measured by the relevant criteria. based on some of the general opinion of the performance can be described as behavior or activities of a person in performing duties or responsibilities as a member of the organization in its efforts to achieve effectiveness and efficiency of the organization. In general it can be said that the performance is a feat that can be achieved by the organization in the period ertentu. it is in line with the concept of performance by Wirawan (2015: 7) is divided into three parts: (1) the performance of the individual; (2) the performance of the group; (3) the performance of the Organization. Meanwhile, according Mangkunagara (2013) is the capability of the performance achieved and the desired behavior of members in the mastery of job tasks so that the quality of work and work attendance is the responsibility of individuals and groups within the organization.

\subsection{Empowerment}

Empowerment is one of the science of human resource management in order to develop a soldier. Empowerment menuntu expanding the role, authority and power and increased flexibility on how the roles were performed (Stewart, 2007: 240). The success of the process of empowerment in a military organization by Khan (2011) is determined by a number of important indicators include:

1) Trust: trust between the leaders and members of the organization, that the lack of mutual trust between members of the organization that will create good conditions for the exchange of information and advice without fear.

2) Credibility: maintaining credibility with awards and developed a work environment that encourages competition Seha so as to create an organization that has high performance.

3) Communication: open communication to create mutual understanding between members and the organization, this openness can be realized with their comments and suggestions on the results and achievements made by the organization's members.

\subsection{Human Capital}

Human Capital is defined as the accumulation of knowledge, expertise, experience, and attributes that are relevant ainnya work force in the labor force and spur produktivtas an organization's performance and the achievement of strategic objectives (Goal, 2014: 696). Demartini and Paoloni (2011: 17) defines human capital as the knowledge of individuals who obtained a person's lifetime and is used to produce goods, ideas or services. by Wohlin, e al. (2015: 231) noted that there are several factors that affect the human capital. Age and gender as factors that influence entrepreneurship education. Factor experience in general the higher the age, education and skills are desirable choice between men and women tend to be the same. Inherent in the individual three resources that complement each ain as part of human capital. The third element of the human capital consists of intellectual abilities.

\subsection{Commitment}

Organizational commitment is a qualitative and a feeling of one's era to the objectives and values of the organization in relation to the role of the members towards achieving the objectives and values of tersebu (Durkin, 2010: 127). Definition of organizational commitment in general is the existence of an agreement or destination 
etap member to become a member of the organization (Robbins and Judge, 2013: 74-75). Meanwhile, according to Gibson e al. (2009: 86) put forward the notion of commitment is keadan involves the identification and loyalty are realized to the organization where a person works.

Commitment is defined as the likelihood that a person will receive the organization's values and mobilize efforts to comply with these values, and will maintain membership in the organization (Chen, e al. 2012: 324). by Kessler (2013) suggests that organizational commitment, namely: about sense of belonging and loyalty to the organization's members caused by organizational affective commitment, continuous commitment and normative commitment.

\subsection{Hypothesis}

Based on the conceptual karangka the formulation of hypotheses of this study are as follows:

H1 : suspected effect of empowerment, human capital and commitment to the performance of soldiers.

H2 : allegedly human capital dominant influence on the performance of soldiers.

\section{Research methods}

\section{1. plan Research}

Designed using explanatory research that aims to test a hypothesis through Home Visits or to strengthen or even reject the theory or hypothesis that already exists. Research aimed at obtaining information, information and data relating to the unknown.

\subsection{Operational definition variables}

1) Performance $(Y)$

Performance is the ability to work achieved and desired behavior of members in carrying out and completing the work tasks that are the responsibility of the individual or group. Indicators: quality of the Work, the task mastery, and Attendance Works.

2) Empowerment (X1)

Empowerment is an activity that is continuous, dynamic, synergistic encourage the involvement of all the potential that exists in evolution with the involvement of all potential. Empowerment of human resources has a superb role determines the performance of organizations and individuals, for it needs an effort to improve the human resource capacity and creating a culture of empowerment. Indicators: trust, credibility, and Communication.

3) Human Capital (X2)

Human Capital is defined as the accumulation of knowledge, expertise, experience, and attributes that are relevant ainnya work force in the labor force and spur produktivtas an organization's performance and the achievement of strategic objectives. Indicators: Education, Skills, Skills, and Training.

4) Commitments (X3)

Commitment is the recognition in full, as the actual attitude that comes from the character that comes out of a person.

Each member of the base and the soldiers have different behavior based on organizational commitment owned. Indicators: Affective Commitment, Sustainable Commitment and Normative Commitment.

\subsection{Population and Sampling Techniques}

Population is the subject of research or analysis of the total number of union whose characteristics are to be expected. The notion of the population in this study were all members of soldiers Yonbekang 2 KOSTRAD numbered 400 soldiers. However, this population is targeted based on years of service soldier more than 10 ear and domiciled in Malang, so found a population of about 114 soldiers. Given the population size is not too large, then the members of the study population is better taken all that this study is a population study or census.

\subsection{Technique ${ }_{\mathrm{i}}$ Data analysis}

The analysis technique used in this research is descriptive analysis and multiple linear regression analysis.

\section{Research Result}

\subsection{Hypothesis testing}

1) First Hypothesis Testing

To test the first hypothesis which states thatNo effect of empowerment, human capital and commitment to the performance of soldiers, By using test F. From the calculation results of multiple regression analysis with SPSS acquired Fhitung 75.372, sedangkaln Ftable at $\alpha=5 \%$, DF1 $=3$, and DF2 $=110$ of 2.70; this means that $F$ count $>\mathrm{F}$ table $(75.372)>2.70)$, while the probability is more ketch of $\alpha=0.05(0.000<0.05)$, then Ho rejected and accepted, which means that the independent variables: empowerment, human capital and commitment 
simultaneously significant effect on the performance of soldiers. Thus the first hypothesis is statistically accepted or tested.

2) Second Hypothesis Testing

To test the second hypothesis which stateshuman capital dominant influence on the performance of soldiers, Using the test. Test is used to test whether each independent variable empowerment, human capital and commitment partially significant effect on the performance of soldiers, by comparing the count with the table. the results of arithmetic calculations and tables of each independent variable is as follows:

Table 2. Comparison of calculated and tables $\alpha=5 \%$

\begin{tabular}{lcccc}
\hline \multicolumn{1}{c}{ Variabell } & $\mathrm{t}$ & ttabel & Sig. & Information \\
\hline Empowerment (X1) & 3.725 & 1,980 & 0,000 & Significant \\
Human capital (X2) & 4.605 & 1,980 & 0,000 & Significant \\
Commitments (X3) & 3.712 & 1,980 & 0,000 & Significant \\
\hline
\end{tabular}

Sources: Primary data is processed.

According to the table above can be explained as follows:

a) Variable empowerment (X1)

Hasi regression analysis calculated value $=3.725$ while the value table $=1,980$ so count $>$ table or significance value $0,000<0,05$ so Ho rejected or accepted thing, and proved empowerment variable (X1) significantly affects the performance of soldiers (Y).

b) Human capital variable (X2)

Hasi regression analysis calculated value $=4.605$ while the value table $=1,980$ so count $>$ table or significance value $0,000<0,05$ so Ho rejected or accepted thing, and proven human capital variable (X2) significantly affects the performance of soldiers (Y).

c) Variable commitment (X3)

Hasi regression analysis calculated value $=3.712$ while the value table $=1,980$ so count $>$ table or significance value $0,000<0,05$ so Ho rejected or accepted thing, and proven commitment variable (X3) significantly affects the performance of soldiers (Y).

Based on the test results, it can be proved that empowerment, human capital and commitment partially significant effect on the performance of soldiers (Y). Meanwhile, to determine which variables are dominant to see the magnitude of the regression coefficient significant effect on the performance of soldiers. The independent variables that have the most substantial and significant coefficient is a variable the dominant influence on the performance of soldiers. Based on the results of multiple regression analysis showed that the greatest regression coefficient that is human capital amounting to 0,384 , this means that human capital is a variable the dominant influence on the performance of soldiers. Thus both statistically acceptable or tested.

\section{Discussion}

\subsection{Description Empowerment, Human capital, Commitment and Performance Soldiers}

Empowerment was formed by the trust, credibility, and communication. The main thing that supports the empowerment that is reflected credibility of the respondents are ready every saa given orders by the leadership. Comfortable empowerment can create semanga work, thus increasing performance. Empowerment becomes something important, because in the era of competition and service, every soldier corps requires cepa considered and independent so that the corps has a competitive advantage through their human resources. Empowerment by corps used as a means to memperkua capability soldiers.

Human capital formed by education, skills, expertise, and training. The main thing that builds human capital is reflected in the respondents' trainingtrained to mengembangankan speed in carrying out the duties and training in improving agility Menta think from all directions, Human capital is kLife Skills, knowledge and competence are the key factors that determine the well-being of the organization.

Commitment is formed by affective commitment, continuous commitment and normative commitment. The main things that can increase a commitment is a commitment reflected normativeas a soldier in Yonbekang 2 Kostrad shouldloyal to the Corps. Commitment to every soldier important dross as with a commitment to a soldier can become a more responsible job than with those that do not have a commitment. Soldiers who have a commitment, will work optimally so as to devote attention, thoughts, enaga and time to work, so that what is already doing as expected by the corps. Soldier performance established by the quality of work, mastery of the task, and work attendance. The main thing that could improve the performance of soldiers is reflected respondents' work attendancepresent each hour service, Performance corps soldier role in the overall success that the high performance required soldiers to be able to complete the job effectively and efficiently.

\subsection{Effect of Empowerment of Soldier Performance}

Empowerment affect the performance of soldiers, which means that the better empowerment can improve the 
performance of soldiers. Empowerment can bring the potential and modalities that exist in soldiers and to make this so that the soldiers be independent and builds up its performance, which in turn provide value manfaa soldiers and corps. With empowerment, it was confirmed that the corps will be able to get and keep a soldier who has qualities, skills, knowledge and capabilities and employ soldier efficiently and efficiently. The results are consistent with theFadzilah (2006), Adhitya (2010) stating that empowering effect on performance.

\subsection{Influence Human capital on Soldiers performance}

Human capital affect the performance of soldiers, which means that the higher the human capital it will cause more soldiers ingginya performance. Human capital that gives the largest contribution to the increase in performance is reflected in the trainingtrained to mengembangankan speed in carrying out the duties and training in improving agility Menta think from all directions. Human capital reflects the collective ability to produce solutions erbaik corps based on the knowledge possessed by the soldiers in the corps, which builds up if the corps is able to use the knowledge possessed by the warrior. resultThis research is in line with Vira (2016) and Nugraha (2018) which states that human capital effect on performance.

\subsection{Influence Commitment to Performance Soldiers}

Commitment affect the performance of soldiers, which means that the higher the soldier's commitment to improve the performance of soldiers. Commitment is a condition of the extent to which a person in favor of a corps of soldiers, and intend to maintain membership in the corps and to maintain the continuity of the corps. Service members who have basic affective organizational commitment have different behavior with members I soldiers based "continuance" or sustainable. Members who wish to be a soldier would have a desire to use the business in accordance with the objectives of the organization. Instead members who are forced to become soldiers will avoid in financial losses and loss ain, so it may only do business that is not optimal. Meanwhile, the normative component cause feelings of obligation on members to reward soldiers for what they have received from the corps. resultThis research is in line withDwiyanti (2016) which states that the commitment effect on performance.

\section{Conclusion}

Hasi descriptive statistics show thatempowerment established by the trust, credibility, and communication. The main thing that supports the empowerment that is reflected credibility of the respondents are ready every saa given orders by the leadership. Human capital is formed by education, skills, expertise, and training. The main thing that builds human capital is reflected in the respondents' trainingtrained to mengembangankan speed in carrying out the duties and training in improving agility Menta think from all directions, Commitment is formed by affective commitment, continuous commitment and normative commitment. The main thing that can increase the commitment is reflected in the normative commitmentas a soldier in Yonbekang 2 Kostrad shouldloyal to the Corps. Soldier performance established by the quality of work, mastery of the task, and work attendance. The main thing that could improve the performance of soldiers is reflected respondents' work attendancepresent each hour service,

Empowerment, human capital and commitments affect the performance of soldiers, which means that the better empowerment, supported by soldiers who have high human capital, and supported by a strong commitment to improve the performance of soldiers. Human capital is the dominant influence on the performance of soldiers in Yonbekang 2 Kostrad Malang. This suggests that the main thing that could improve the performance of soldiers are human capital, especially training.

\section{Suggestion}

Should the corps creates good communication between soldiers and superiors. We recommend that every soldier constantly improve their skills by means of training. So that soldiers have a high commitment, the corps should create a conducive working atmosphere, so that soldiers feel comfortable and happy to work in the corps, For further research, is expected to undertake research development using another independent variable, so it can provide better agi influence on the performance of soldiers.

\section{Reference}

Anis Dwiyanti, 2016, Pengaruh Lingkungan Kerja, Disiplin Kerja, Kompensasi, Komitmen Terhadap Kinerja Karyawan PT. Kebon Agung PG. Trangkil di Pati, Jurnal Ekonomi dan Bisnis, Universitas Diponogoro, Semarang.

Chen, Mavis Yi-C, Yung S. W, and Vicky S, 2012, Intellectual Capital and Organizational Cimmitment Evidence From Cultural Creative Industries in Taiwan, Personnel Review, Vol.41 No.3 pp, 321 - 339.

Chunghtai Amir Ali, 2013, Linking Affective Commitment to Supervisor to Work Outcomes, Journal of Managerial Psychology, Vol. 28 No. 6 pp, $606-627$.

Crook, T. Russell, Samuel Y. Todd, James G. Combs dan David J. Woehr, 2011. Does Human Capital Matter? A 
Meta-Analysis of the Relationship Between Human Capital and Firm Performance, Journal of pplied Psychology, Vol. 96 No.3 pp. 443 -456.

Colquit, Jason A, Jeffery A, Lepine dan Michael J, Wesson, 2011, Organizational Behavior, New York, McGrawHill.

Demartini Paola dan Paola Paoloni, 2011, Assessing Human Capital in Knowledge Intensive Business Service, Measuring Business Excellence, Vol. 15 No. 4.

Goal, CHR, Jimmy L, 2014, A to Z Human Capital Manajemen Sumber Daya Manusia, Penerbit PT. Grasindo Anggota Ikapi, Jakarta.

Hayek, Mario, Christopher H. Thomas, Milorad M, Novicevic dan Daniel Montalvo, 2014, Contextualizing human capital theory in a non-Western setting: Testing the pay-for-performance assumption, Jurnal of Business Research, Vol.10.No.1 pp. 1-8.

Jarrar Yasar F dan Mohamad Zairi, 2012, Employee Empowerment - a UK survey of trends and best practice, Management Auditing Jurnal, Vol.17, No 5 pp. 266 - 2012.

Khan et al, 2011, Job Involvement as Predictor of Employee Commitmen Evidence from Pakistan, International Journal of Business and Management Vol. 6 No. 4 April,2011.

Kazlauskaite, Rosenzweig, Ilona B, Linas T, 2012, Organisational and Psychological Empowerment in The HRM - Performance Linkage, Employee Relations, Vol. 34 No.2 pp, 138 - 158

Kessler E H, 2013, Encyclopedia of Management Theory, Volume 2, Los Angeles, SAGE Publications, Inc.

Khasawneh Samer, 2011, Human Capital Planning in Higher Education Institutions A Strategic Human Resource Development Initiative in Jordan, International Journal of Education Management, Vol. 25 No. 6 pp, 534 544.

Lafuente E, Rodrigo Rabetino, 2011, Human Capital and Growth in Romanian Small Firms, Journal of Small Business and Enterprise Development, Vol. 18 No. 1 pp, 77 - 96.

Mangkunegara Anwar Prabu, 2013, Manajemen Sumber Daya Manusia, Remaja Rosdakarya, Bandung.

Prayedi Cahya Nugraha, 2018, Pengaruh Human Capital terhadap Kinerja Perusahaan, Jurnal Administrasi Bisnis, Vol. 57 No.2, April 2018.

Puig,Vicente Roca, Inmaculada Beltran Martin dan Mercedes Seggra Cipres, 2012, Combined Effect of Human Capital, Temporary Employment and Organizational Size on Firm Performance, Personnel Review, Vol. 41 No. 1 pp, $4-22$.

Robbins Stephen P dan Timothy A. Judge, 2013, Organizational Behavior, 15th ed. Pearson Prentice Hall, New Jersey.

Sanusi Anwar, 2011, Metodologi Penelitian Bisnis Disertai Contoh Proposal Penelitian Bidang Ilmu Ekonomi dan Manajemen, Penerbit Salemba Empat, Jakarta.

Samad Sarminah, 2013, Assessing the Contibution of Human Capital on Bussiness Performance, International Journal of Trade, Economics and Finance, Vol. 4, No.6 pp. 393 - 397.

Setiawan I Putu \& Piartrini Soroyini, 2018, Pengaruh Pemberdayaan Karyawan dan Stres Kerja Terhadap Komitmen Organisasional Karyawan Departemen Housekeeping pada Villa Ocean Blue, Jurnal Ekonomi dan Bisnis Universitas Udayana Bali.

Simanjuntak Payaman J, 2011, Manajemen dan Evaluasi Kinerja, Fakultas Ekonomi Universitas Indonesia, Jakarta.

Sobahi Karna dan Suhana Cucu, 2011, Pemberdayaan Masyarakat dalam Pendidikan di Era Otonomi Daerah, CV. Cakra, Bandung.

Virajati, 2016, Daftar Penilaian dan Human Capital terhadap Kinerja Prajurit TNI-AD, Jurnal Sekolah Staf dan Komando Angkatan Darat, Edisi 1, Bandung.

Wirawan, 2015, Evaluasi Kinerja Sumber Daya Manusia, Teori Aplikasi dan Penelitian, Penerbit Salemba Empat, Jakarta.

Wohlin C, Darja S and Nils B M, 2015, A General Theory of Software Engineering: Balancing Human, Social and Organizational Capitals, The Journal of Systems and Software, Vol.119 pp, $229-242$. 